\title{
Correlation of body composition parameters using different methods among Brazilian obese adults
}

\section{Correlação de parâmetros de composicão corporal utilizando diferentes métodos entre adultos obesos brasileiros}

\author{
Lívia Santana Neves Máximo ${ }^{1}$ \\ (D) https://orcid.org/0000-0001-8141-7702 \\ Flávia Franca Melo \\ (iD) https.//orcid org/0000-0002-8065-9416 \\ Lara Benigno Porto ${ }^{1}$ \\ (iD) https://orcid.org/0000-0002-1993-6584 \\ Izabel Cristina Rodrigues da Silva \\ (D) https://orcid.org/0000-0002-6836-3583 \\ Mirley do Prado ${ }^{3}$ \\ (D) https://orcid org/0000-0001-6799-5581 \\ Hermelinda Cordeiro Pedrosa \\ (D) https://orcid.org/0000-0002-2266-8082
}

Abstract - Data comparing anthropometric measurements, bioelectrical impedance analysis (BIA) and dual-energy X-ray absortiometry (DXA) parameters are somehow limited and conflicting. The objective of this study was to correlate anthropometric, BIA and DXA parameters among obese Brazilian adults with focus on the comparison with visceral adipose tissue (VAT) obtained from DXA and in the value of antropometric measurements. Fifty voluntary participants were enrolled. The Spearman correlation test was used to assess the correlation of VAT with anthropometric measurements, BIA and other DXA parameters. The intra-class correlation coefficient (ICC) was used to evaluate concordance between lean mass (LM), fat mass (FM), \%body fat (\%BF) and \%upper body fat (\%UBF) obtained from BIA and DXA. Most were female (80\%) and had an average body index mass (BMI) of $39.0( \pm 6.4) \mathrm{kg} / \mathrm{m}^{2}$. The only anthropometric measurements showing a strong correlation with VAT were abdominal circumference (AC) and waist-to-height ratio (WHtR), but just in females. There was a very good correlation for $\mathrm{LM}[\mathrm{ICC}=0.951(\mathrm{CI}=0.913-0.972)], \mathrm{FM}[\mathrm{ICC}=0.987(\mathrm{CI}=$ $0.977-0.993)], \% \mathrm{BF}[\mathrm{ICC}=0.961(\mathrm{CI}=0.931-0.978)]$, and $\% \mathrm{UBF}[\mathrm{ICC}=0.873(\mathrm{CI}=$ $0.776-0.928)]$, between data collected through BIA and DXA. Among the anthropometric measurements assessed, only $\mathrm{AC}$ and $\mathrm{WHtR}$ seems to estimate patients with abdominal fat distribution and higher VAT in females. DXA and BIA proved similar for the evaluation of $\mathrm{LM}, \mathrm{FM}, \% \mathrm{BF}$ and \%UBF, although DXA has the advantage of estimating VAT.

Key words: Anthropometry; Body composition; Dual-energy X-ray absorptiometry; Electric impedance; Obesity.

Resumo - Dados comparando medidas antropométricas, análise de impedância bioelétrica (BLA) e parâmetros de absorciometria de raios- $X$ de dupla energia (DXA) são de alguma forma limitados e conflitantes. O objetivo deste estudo foi correlacionar parâmetros antropométricos de BLA e de DXA entre adultos obesos brasileiros, com foco na comparação com tecido adiposo visceral (TAV) obtido na DXA e no valor das medidas antropométricas. Cinquenta participantes voluntários foram inscritos. O teste de correlação de Spearman foi utilizado para avaliar a correlaçâa do TAV com medidas antropométricas, da BIA e de outros parâmetros da DXA. O coeficiente de correlação intra-classe (ICC) foi usado para avaliar a concordância entre massa magra (MM), massa gorda (MG), \% de gordura corporal (\%GC) e \% de gordura corporal na parte superior do corpo (\%GSC) obtidos por BIA e DXA. A maioria era do sexo feminino (80\%) e apresentava indice de massa corporal médio (IMC) de 39,0 $( \pm 6,4) \mathrm{kg} / \mathrm{m} 2$. As únicas medidas antropométricas que mostraram uma forte correlação com o TAV foram a circunferência abdominal (CA) e a relação cintura / estatura (RCE), mas apenas no sexo feminino. Houve uma correlação muito boa para $M M[I C C=0,951(I C=0,913-0,972)], M G$ $[I C C=0,987(I C=0,977-0,993)], \% G C[I C C=0,961(I C=0,931-0,978)]$, e \% GSC [ICC $=0,873(I C=0,776-0,928)]$, entre os dados coletados através de BIA e DXA. Dentre as medidas antropométricas avaliadas, apenas a $C A$ e a RCE parecem estimar pacientes com distribuição de gordura abdominal e maior TAV no sexo feminino. A DXA e a BLA mostraram-se semelhantes para a avaliação de $M M, M G, \%$ GC e \% GSC, embora a DXA tenha a vantagem de estimar o VAT.

Palavras-chave: Antropometria; Composição corporal; Densitometria; Impedância elétrica; Obesidade.
1 Unit of Endocrinology of the Regional Hospital of Taguatinga and Research Centre of the Foundation for Education and Research in Health Sciences, Secretariat of Health of the Federal District. Brasilia, DF. Brazil.

2 Faculty of Ceilândia. University of Brasilia. Brasilia, DF. Brazil.

3 Janice Lamas Radiologic Clinic. Brasilia, DF. Brazil.

Received: 03 December 2018 Accepted: 30 August 2019

How to cite this article Máximo LSN, Melo FF, Porto LB, Silva ICR, Prado M, Pedrosa HC. Correlation of body composition parameters using different methods among Brazilian obese adults. Rev Bras Cineantropom Desempenho Hum 2019, 21:e60539. DOI: http://dx.doi.org/10.1590/19800037.2019v21e60539

Copyright: This work is licensed under a Creative Commons Attribution 4.0 International License. 


\section{INTRODUCTION}

Obesity is defined by the World Health Organization (WHO) as a body mass index (BMI) greater than or equal to $30 \mathrm{~kg} / \mathrm{m}^{2}$, and is considered a chronic disease with high morbidity and difficult to treat ${ }^{1}$. Obesity favors the occurrence of other diseases such as dyslipidemia, hypertension, type 2 diabetes mellitus (DM2), cardiovascular diseases, degenerative joint disease, apnea and various types of cancer (breast, liver, colon, cervix, prostate and others) $)^{2}$.

In the last four decades, the prevalence of obesity has increased in epidemic proportions throughout the world. In Brazil, from 2006 to 2016, the prevalence of obese people increased from $11.8 \%$ to $18.9 \%{ }^{3}$. The usual definition of obesity, based solely on body index mass (BMI), is limited because does not distinguish the location of adiposity and the different body structures, nor the variations that occur in the body with age. Furthermore, it is well established that among the components of abdominal fat, visceral fat is most predictive of adverse cardiovascular events than subcutaneous fat. Large quantities of visceral adipose tissue (VAT) are associated with metabolic syndrome, insulin resistance, type 2 diabetes (DM2) and cardiovascular disease, through mechanisms not fully elucidated ${ }^{4-7}$.

Adiposity can be assessed by different methods such as anthropometric measurements, bioelectrical impedance analysis (BIA), Dual-energy X-ray absorptiometry (DXA), computed tomography, ultrasound and magnetic resonance imaging, each with its advantages and disadvantages, some more expensive and others requiring more complex equipment, resulting in limited large-scale use $\mathrm{e}^{8-10}$.

Anthropometric measurements are still the most widely used way to estimate body composition because of its simplicity, convenience and low $\operatorname{cost}^{11}$. BIA is a rapid, practical, minimally invasive and relatively inexpensive instrument used to analyze body composition of individuals based on the electrical conductivity of tissues ${ }^{12,13}$. DXA is often referenced in the literature and is regarded in clinical practice as the 'gold standard' for this kind of assessment; it is a simpler, generally safer and faster technique than other modalities for serial measurements of body composition ${ }^{14-16}$. Therefore, the objective of this study was to correlate anthropometric, BIA and DXA parameters among obese Brazilian adults with focus on the comparisson with VAT derived from DXA and in the value of antropometric measurements.

\section{METHOD}

\section{Subjects}

This was a cross-sectional study, which involved 50 voluntary participants with a diagnosis of obesity and monitored at the Endocrinology Unit of the Regional Hospital of Taguatinga (UENDO-HRT), Distrito Federal, Brazil. The protocol of this study was approved by the Ethics Commit- 
tee on Human Research of the Health State Secretariat of the Federal District/ Foundation for Education and Research in Health Sciences, number 47544515.0.0000.5553. All participants completed the Consent Agreement.

Inclusion criteria were: $\mathrm{BMI} \geq 30 \mathrm{~kg} / \mathrm{m}^{2}$, aged 18 to 65 , body weight up to $204 \mathrm{~kg}$ and height up to $195 \mathrm{~cm}$. Exclusion criteria were: pregnant women, use of a metallic prosthesis, pacemakers or defibrillators, cardiac, liver or kidney failures.

\section{Design and Procedures}

The selected participants were subjected to: (1) medical consultation associated with anthropometric assessment, (2) measures of BIA and (3) measures of DXA. Medical consultation was based on the completion of a form designed specifically for this work that included: identification, age, gender, race, occupation, medical history, current medications, and lifestyle habits. Anthropometric evaluation assessed weight, height, BMI, abdominal circumference (AC), hip circumference (HC), waist-tohip circumference ratio (WHR), the waist-to-height ratio (WHtR), and conicity index (CIx). All measurements were performed three times by the same examiner, and the final numbers were the arithmetic average of all three measures.

BIA was performed using the portable bioelectrical multi-frequency impedance analyzer In Body $230{ }^{\circledR}(20 \mathrm{kHz}$ to $100 \mathrm{kHz})$ and quadrupole with 8 points ( 2 tactile electrodes arranged on each limb). Whole body DXA scan was held using the equipment Lunar iDXA DXA System (enCORE software, version 14.10), produced by GE Healthcare ${ }^{\circledR}$. The analysis was performed by the same observer and followed the recommendations of ABRASSO (Brazilian Association of Bone Evaluation and Osteometabolism - official position from 2008) and ISCD (International Society of Clinical Densitometry - official positions from 2013).

\section{Statistical methods}

Sample size calculation was assumed as part of an infinite population, with an error margin of $10 \%$ to determine the sampling, which was obtained for convenience. Inclusion criteria were: age equal or greater than 18 and free and spontaneous inclusion in the study. With a distribution response of $15 \%$, the required minimum sample size was 49 participants.

For inferential analysis, first, the assumptions of normality by the Shapiro-Wilk test were checked. For those with Gaussian distribution, the results were expressed as mean ( \pm standard deviation) and Student's t-test was used. For those that did not present Gaussian distribution, the results were expressed in median ( \pm inter-quartile interval) and the MannWhitney test was used. Spearman correlation test was used to assess the correlation of VAT with all the other quantitative variables.

For confidence among methodologies using BIA and DXA, the intraclass correlation coefficient (ICC, mixed two-way), was used to evaluate 
concordance between lean mass (LM), fat mass (FM), \%body fat (\%BF) and \%upper body fat (\%UBF) obtained from BIA and DXA.

The level of significance was set at $\mathrm{p}$-value $<0.05$. All analysis was performed using the Statistical Package for Social Sciences (SPSS), version 22.0.

\section{RESULTS}

In the total sample, the majority was female (80\%), mean age was $43.7 \pm$ 11.6 years and mean of BMI was $39.0 \pm 6.4 \mathrm{~kg} / \mathrm{m}^{2}$. Among men, there was a bigger amount of LM and less \%BF and \%UBF also by BIA and DXA; although the pattern of fat distribution seemed to be less favorable with more VAT, \%android fat and android-gynoid ratio by DXA in males. General antropometric measurements, BIA and DXA results are shown in Table 1.

Table 1. Anthropometric measurements, BIA and DXA parameters of the total sample.

\begin{tabular}{|c|c|c|c|c|}
\hline \multicolumn{5}{|c|}{ Anthropometric measurements } \\
\hline & $\begin{array}{l}\text { Overall } \\
(n=50)\end{array}$ & $\begin{array}{l}\text { Women } \\
(n=40)\end{array}$ & $\begin{array}{c}\text { Men } \\
(n=10)\end{array}$ & P-Value* \\
\hline Age (years) ${ }^{a}$ & $47.3( \pm 11.6)$ & $43.0( \pm 11.4)$ & $46.7( \pm 12.3)$ & 0.364 \\
\hline Weight $(\mathrm{kg})^{\mathrm{b}}$ & $101.4( \pm 24.1)$ & $100.0( \pm 22.2)$ & $109.7( \pm 33.8)$ & 0.054 \\
\hline Height $(\mathrm{cm})^{\mathrm{a}}$ & $163.3( \pm 9.1)$ & $160.0( \pm 5.5)$ & $177.7( \pm 5.2)$ & 0.364 \\
\hline BMI $\left(\mathrm{kg} / \mathrm{m}^{2}\right)^{\mathrm{b}}$ & $39.2( \pm 7.1)$ & $39.6( \pm 6.1)$ & $34.2( \pm 10.0)$ & 0.104 \\
\hline $\mathrm{AC}(\mathrm{cm})^{\mathrm{a}}$ & $114.7( \pm 12.1)$ & $113.1( \pm 11.8)$ & $121.0( \pm 11.4)$ & 0.063 \\
\hline $\mathrm{HC}(\mathrm{cm})^{\mathrm{b}}$ & $123.0( \pm 19.3)$ & $124.5( \pm 16.0)$ & $115.5( \pm 20.5)$ & 0.112 \\
\hline WHtR ${ }^{a}$ & $0.7( \pm 0.1)$ & $0.7( \pm 0.1)$ & $0.7( \pm 0.1)$ & 0.270 \\
\hline WHR $^{\mathrm{a}}$ & $0.9( \pm 0.1)$ & $0.9( \pm 0.1)$ & $1.0( \pm 0.1)$ & $0.000^{\#}$ \\
\hline $\mathrm{Cl}^{\mathrm{b}}$ & $2.0( \pm 0.2)$ & $1.9( \pm 0.2)$ & $2.1( \pm 0.3)$ & $0.002^{\#}$ \\
\hline \multicolumn{5}{|l|}{ BIA Results } \\
\hline & $\begin{array}{l}\text { Overall } \\
(n=50)\end{array}$ & $\begin{array}{l}\text { Women } \\
(n=40)\end{array}$ & $\begin{array}{c}\text { Men } \\
(n=10)\end{array}$ & P-Value \\
\hline $\mathrm{LM}(\mathrm{kg})^{\mathrm{a}}$ & $31.4( \pm 6.9)$ & $28.9( \pm 4.5)$ & $41.7( \pm 5.7)$ & $0.000^{\#}$ \\
\hline $\mathrm{FM}(\mathrm{kg})^{\mathrm{b}}$ & $46.4( \pm 17.5)$ & $48.7( \pm 16.3)$ & $39.7( \pm 18.0)$ & 0.115 \\
\hline Free fat mass $(\mathrm{kg})^{\mathrm{b}}$ & $52.5( \pm 17.5)$ & $50.8( \pm 9.4)$ & $76.0( \pm 13.9)$ & $0.000^{\#}$ \\
\hline$\% \mathrm{BF}^{\mathrm{a}}$ & $45.9( \pm 6.9)$ & $48.4( \pm 4.4)$ & $36.2( \pm 6.6)$ & $0.000^{\#}$ \\
\hline$\% U_{B F}{ }^{a}$ & $45.0( \pm 4.8)$ & $46.8( \pm 2.8)$ & $37.8( \pm 4.5)$ & $0.000^{\#}$ \\
\hline \multicolumn{5}{|l|}{ DXA Results } \\
\hline & $\begin{array}{l}\text { Overall } \\
(n=50)\end{array}$ & $\begin{array}{l}\text { Women } \\
(n=40)\end{array}$ & $\begin{array}{c}\text { Men } \\
(n=10)\end{array}$ & P-Value \\
\hline $\operatorname{VAT}\left(\mathrm{cm}^{3}\right)^{\mathrm{b}}$ & $1,734.0( \pm 1,062.0)$ & $1,665.0( \pm 724.0)$ & $3,496.0( \pm 1911.0)$ & $0.000^{\#}$ \\
\hline Fat Mass Index a & $18.3( \pm 5.0)$ & $18.6( \pm 6.0)$ & $13.4( \pm 6.3)$ & $0.001^{\#}$ \\
\hline LM $(\mathrm{kg})^{\mathrm{a}}$ & $51.3( \pm 9.9)$ & $28.9( \pm 4.5)$ & $41.7( \pm 5.7)$ & $0.000^{\#}$ \\
\hline $\mathrm{FM}(\mathrm{kg})^{\mathrm{b}}$ & $47.3( \pm 15.5)$ & $48.6( \pm 16.3)$ & $39.7( \pm 18.0)$ & 0.133 \\
\hline$\% \mathrm{BF}^{\mathrm{b}}$ & $47.0( \pm 6.6)$ & $48.0( \pm 7.2)$ & $36.3( \pm 12.7)$ & $0.000^{\#}$ \\
\hline$\% U_{B F}{ }^{a}$ & $52.2( \pm 6.3)$ & $53.9( \pm 4.8)$ & $45.5( \pm 7.5)$ & $0.000^{\#}$ \\
\hline$\%$ Android fat ${ }^{a}$ & $55.5( \pm 6.8)$ & $57.2( \pm 5.5)$ & $48.9( \pm 7.7)$ & $0.000^{\#}$ \\
\hline$\%$ Gynoid fat ${ }^{\mathrm{a}}$ & $48.6( \pm 8.5)$ & $51.7( \pm 5.1)$ & $36.1( \pm 7.8)$ & $0.000^{\#}$ \\
\hline Android-gynoid ratio ${ }^{a}$ & $1.2( \pm 0.2)$ & $1.1( \pm 1.0)$ & $1.4( \pm 0.1)$ & $0.000^{\#}$ \\
\hline
\end{tabular}

Note. $\mathrm{BI} A=$ bioelectrical impedance analysis; $\mathrm{DXA}=$ dual-energy $\mathrm{X}$-ray absortiometry; $\mathrm{BMI}=$ body mass index; $\mathrm{AC}=$ abdominal circumference; $\mathrm{HC}=$ hip circumference; WHtR = waist-to-height ratio; WHR = waist-to-hip circumference ratio; $\mathrm{Cl}$ = conicity index; $\mathrm{LM}=$ lean mass; FM = fat mass; \%BF = body fat; \%UBF = \%upper body fat; $V A T$ = visceral adipose tissue; a Data expressed as mean ( \pm standard deviation); b Data expressed as median ( \pm inter-quartile interval); ${ }^{*}$ Results obtained from Student's t-test or Mann-Whitney test; \# P-value $<0.05$ 
In general, the only anthropometric measurements showing a strong correlation with VAT in females were AC and WHtR. In men, no anthropometric parameter had strong association with VAT (Table 2).

Regarding BIA, correlations with VAT were null for males and moderate for FM in females. Therefore, no BIA parameter was shown to have a strong correlation with VAT (Table 3).

Concerning DXA, none of the other parameters evaluated by this method showed a strong correlation with VAT. Correlations were moderate for \%UBF and \% android fat in both genders (Table 4).

Table 2. Correlation of VAT and anthropometric parameters.

\begin{tabular}{lcccc}
\hline & $\begin{array}{c}\text { Female VAT }\left(\mathrm{cm}^{3}\right) \\
(\mathrm{n}=40)\end{array}$ & P-value & $\begin{array}{c}\text { Male VAT }\left(\mathrm{cm}^{3}\right) \\
(\mathrm{n}=10)\end{array}$ & P-value \\
\hline BMI & $0.443^{*}$ & 0.004 & 0.358 & 0.310 \\
AC & $0.761^{* *}$ & 0.000 & 0.358 & 0.310 \\
HC & $0.369^{*}$ & 0.019 & 0.248 & 0.489 \\
WHtR & $0.741^{* *}$ & 0.009 & 0.406 & 0.244 \\
WHR & $0.409^{*}$ & 0.001 & 0.273 & 0.446 \\
Clx & $-0,259$ & 0.106 & -0.358 & 0.310 \\
\hline
\end{tabular}

Note. VAT = visceral adipose tissue $; \mathrm{BMI}=$ body mass index; $\mathrm{AC}=$ abdominal circumference; $\mathrm{HC}$ = hip circumference; $\mathrm{WHtR}=$ watist-to-height ratio; $\mathrm{WHR}$ = waist-to-hip circumference ratio; $\mathrm{Clx}$ = conicity index; All the results were obtained from Spearman correlation coefficient test; ${ }^{*}$ Weak correlation with statistical significance set at $p$-value $<0.05$; ${ }^{* *}$ Strong correlation with statistical significance set at $p$-value $<0.05$.

Table 3. Correlation of VAT with BIA parameters

\begin{tabular}{lcccc}
\hline & $\begin{array}{c}\text { Female VAT }\left(\mathrm{cm}^{3}\right) \\
(\mathrm{n}=40)\end{array}$ & P-value & $\begin{array}{c}\text { Male VAT }\left(\mathrm{cm}^{3}\right) \\
(\mathrm{n}=10)\end{array}$ & P-value \\
\hline LM & $0.321^{*}$ & 0.043 & -0.018 & 0.960 \\
FM & $0.523^{* *}$ & 0.001 & 0.309 & 0.385 \\
Free FM & $0.325^{*}$ & 0.040 & -0.042 & 0.907 \\
\%BF & $0.463^{*}$ & 0.003 & 0.406 & 0.244 \\
\%UBF & $0.453^{*}$ & 0.003 & 0.394 & 0.260 \\
\hline
\end{tabular}

Note $L M=$ lean mass: $F M=$ fat mass: $\% B F=\%$ body fat $\% U B F=\%$ upper body fat; $V A T=$ visceral adipose tissue; All the results were obtained from Spearman correlation coefficient test; ${ }^{*}$ Weak correlation with statistical significance set at $p$-value $<0.05$; ** Moderate correlation with statistical significance set at $p$-value $<0.05$.

Table 4. Correlation of VAT with other DXA parameters.

\begin{tabular}{lcccc}
\hline & $\begin{array}{c}\text { Female VAT }\left(\mathrm{cm}^{3}\right) \\
(\mathrm{n}=40)\end{array}$ & P-value & $\begin{array}{c}\text { Male VAT }\left(\mathrm{cm}^{3}\right) \\
(\mathrm{n}=10)\end{array}$ & P-value \\
\hline LM & $0.337^{*}$ & 0.033 & -0.248 & 0.489 \\
FM & $0.504^{* *}$ & 0.001 & 0.442 & 0.200 \\
FM Index & $0.478^{*}$ & 0.002 & 0.527 & 0.117 \\
\%BF & $0.428^{*}$ & 0.006 & 0.564 & 0.090 \\
\%UBF & $0.663^{* *}$ & 0.000 & $0.661^{* *}$ & 0.038 \\
\%Android fat & $0.591^{* *}$ & 0.000 & $0.661^{* *}$ & 0.038 \\
\%Gynoid fat & 0.030 & 0.854 & 0.491 & 0.150 \\
Android-Gynoid ratio & $0.551^{* *}$ & 0.000 & 0.043 & 0.907 \\
\hline
\end{tabular}

Note. $\mathrm{LM}=$ lean mass; $\mathrm{FM}=$ fat $\mathrm{mass} ; \% \mathrm{BF}=$ body fat; \%UBF = upper body fat; VAT = visceral adipose tissue; All the results were obtained from Spearman correlation coefficient test; ${ }^{*}$ Weak correlation with statistical significance set at $p$-value $<0.05 ;{ }^{* *}$ Moderate correlation with statistical significance set at $p$-value $<0.05$. 
There was a very good correlation for lean mass (ICC 0.95), fat mass (ICC 0.99), \% total body fat (ICC 0.96) and \% upper body fat (ICC 0.87) between data collected through BIA and DXA (Table 5).

Table 5. Concordance correlation coeficiente between main parameteres on BIA and DXA

\begin{tabular}{lccc}
\hline & \multicolumn{1}{c}{ BIA $^{a}$} & DXA $^{a}$ & ICC $(\mathrm{Cl})$ \\
\hline LM & $29.4( \pm 10.3)$ & $48.7( \pm 13.5)$ & $0.95(0.913-0.972)$ \\
FM & $46.4( \pm 17.5)$ & $47.3( \pm 15.5)$ & $0.99(0.977-0.993)$ \\
$\%$ BF & $47.5( \pm 8.7)$ & $47.0( \pm 6.0)$ & $0.96(0.931-0.978)$ \\
$\%$ UBF & $46.0( \pm 5.6)$ & $53.1( \pm 8.5)$ & $0.87(0.776-0.928)$ \\
\hline
\end{tabular}

Note. $\mathrm{LM}=$ lean mass; $\mathrm{FM}$ = fat mass; $\mathrm{BF}=$ body fat; $\mathrm{UBF}=$ upper body fat; $\mathrm{ICC}=$ Intraclass correlation coeficiente; $\mathrm{Cl}=$ confidence interval; a Data expressed as median ( \pm inter-quartile interval)

When evaluated athropometric parameters according to correlation with BIA and DXA parameters besides VAT, it was observed for BMI a strong correlation only with FM for BIA on both sexes $(\mathrm{CC}=0.90, \mathrm{P}<0.001)$. For DXA the correlation of BMI was strong only with FM and FM index in women (CC>0.75, P <0.001 for both) and FM, FM index, \%BF, \%UBF and \%android fat, \%gynoid fat in men (CC>0.75, $\mathrm{P}<0.001$ for all of them).

Regarding AC and WHtR among woman, none result on BIA or DXA parameters, besides VAT, presented strong correlation with these variables. While among men, the correlation of $\mathrm{AC}$ was strong with $\mathrm{FM}$ and $\% \mathrm{UBF}$ (by BIA, CC>0.75, $\mathrm{P}<0.001$ for all) and FM, FM index, \%BF, \%android fat and \%gynoid fat (by DXA, CC>0.75, P <0.001 for all). For WHtR in males the correlation was strong with $\mathrm{FM}, \% \mathrm{BF}$ and $\% \mathrm{UBF}$ (by BIA, $\mathrm{CC}>0.75, \mathrm{P}<0.001$ for all); and FM, FM index, \%BF, \%UBF, \%android fat and \%gynoid fat (by DXA, CC $>0.75, \mathrm{P}<0.001$ for all).

Finally, WHR and CIx showed weak correlations with most of the parameters evaluated by the two methods.

\section{DISCUSSION}

Visceral adipose tissue assessed with different techniques has emerged as a potential marker to evaluate cardio metabolic risk ${ }^{4,14,17-20}$. It has been shown that DXA is an adequate tool to assess this parameter ${ }^{5,14,17,21}$. The study by Kaul et al. ${ }^{5}$ reported that VAT evaluated by DXA had a moderate correlation with AC and weak correlation with BMI and WHR. Bertin et al. ${ }^{12}$ concluded in another study that AC and WHR showed moderate correlation with VAT. In the research reported here, in turn, AC and WHR were strongly correlated with VAT in obese adults, but only in females. Maybe the small number of male patients can have influenced these results. Another possibility is a potential limitation of anthropometry to estimate visceral fat in obese males, further research are necessary to clarify this topic.

We found that among women FM estimated by BIA presented moderate correlation with VAT while $\% \mathrm{BF}$ and $\% \mathrm{UBF}$ presented weak correlation. Some authors verified strong agreement between visceral fat area obtained by BIA when this specific measure was compared with values obtained from DXA 
or computed tomography, but general parameters obtained by BIA were not evaluated $^{22,23}$. Kaul et al. observed variable correlation between DXA-derived VAT and other DXA parameters ${ }^{5}$. In our study, DXA-derived VAT presented a moderate correlation with \%UBF and \%android fat in both genders.

Our analysis showed a strong concordance between the BIA and DXA for $\mathrm{LM}, \mathrm{FM}, \% \mathrm{BF}$ and $\% \mathrm{UBF}$, which were results provided by the two methods. Others researches have found similar results when evaluating $\% \mathrm{BF}^{12,13,16}$, although only one of them assessed others BIA-derived parameters in obese patients with resembling findings as ours ${ }^{12}$. It has to be said that variables like age, gender, ethnicity, degree of obesity; BIA devices and equations may influence the agreement between both techniques ${ }^{24,25}$.

Literature data comparing anthropometric measurements with results of BIA and DXA are limited and conflicting. In our study, BMI was strongly correlated with FM for BIA and DXA parameters for both genders. Therefore, this index is better for predicting the amount of fat mass than lean mass. Abdominal circumference and WHtR did not present strong correlation with BIA and DXA parameters among woman, except for DXA-derived VAT. These anthropometric measures were strongly correlated with several results of BIA e DXA in males, what did not happen in females. WHR and CIx did not seem to be very useful in the context of obesity risk prediction.

As limitations for this study we can mention that the patients were evaluated on a single occasion; it would be interesting to carry out the assessment at two time-points, to see if these results are the same for changes in fat mass over time. Also, the relatively small number of patients and the preponderance of woman may also have influenced the differences between genders. It is important to not over-interpret the results of this cross-sectional study. However, none of the limitations exposed invalidate data presented here.

\section{CONCLUSION}

The only parameters strongly correlated with VAT were AC and WHtR in females. Among man, several parameters of BIA and DXA showed robust correlation with $\mathrm{AC}$ and $\mathrm{WHtR}$. The combined use of $\mathrm{AC}$ and WHtR potentially adds value to the recognized limitations of BMI to define obesity in women. BIA and DXA presented robust concordance when we evaluated the parameters that were analyzed jointly by the two methods among obese patients. However, we must emphasize that DXA appears more advantageous to provide additional information, such as VAT measures. Although further studies are necessary, the research presented here provides valuable new data for the Brazilian context.

\section{Acknowledgments}

Janice Lamas Radiology Clinic provided support for this study and the use of DXA. We also would like to thank all the volunteers that participated in the study. Special thanks to ESCREVER CIÊNCIA for scientific advice during manuscript preparation http://www.assessoriaciencia.com. 


\section{COMPLIANCE WITH ETHICAL STANDARDS}

\section{Funding}

There was no funding for this research.

\section{Ethical approval}

Ethical approval was obtained from the local Human Research Ethics Committee of the Foundation for Education and Research in Health Sciences of the Secretariat of Health of the Federal District and the protocol (no. 47544515.0.0000.5553) was written in accordance with the standards set by the Declaration of Helsinki.

\section{Conflict of interest statement}

The authors have no conflict of interests to declare.

\section{Author Contributions}

Conceived and designed the experiments: LSNM, FFM, HCP. Performed the experiments: LSNM, MP. Analyzed the data: LBP, ICRS. Contributed reagents/materials/analysis tools: MP. Wrote the paper: LSNM, FFM, LBP, HCP.

\section{REFERENCES}

1. WHO. Obesity: preventing and managing the global epidemic. Report of a WHO consultation. Technical Report Series. Geneva. World Health Organization, 2000. Report No 894.

2. Khan A, Raza S, Khan $Y$ et al. Current updates in the medical management of obesity. Recent Pat Endocr Metab Immune Drug Discov 2012; 6: 117- 28.

3. Vigitel Brasil Saúde 2016 - Ministério da Saúde. http://portalarquivos.saude.gov. br/images/pdf/2017/abril/17/Vigitel.pdf.

4. Katzmarzyk PT, Greenway FL, Heymsfield SB, Bouchard C. Clinical utility and reproducibility of visceral adipose tissue measurements derived from dual-energy $\mathrm{X}$-ray absorptiometry in White and African American adults. Obesity (Silver Spring) 2013; 21(11): 2221-4.

5. Kaul S, Rothney MP, Peters DM, Wacker WK, Davis CE, Shapiro MD, et al. Dual-energy x-ray absorptiometry for quantification of visceral fat. Obesity 2012; 20: 1313-1318.

6. Kaess BM, Pedley A, Massaro JM, Murabito J, Hoffmann U, Fox CS. The ratio of visceral to subcutaneous fat, a metric of body fat distribution, is a unique correlate of cardiometabolic risk. Diabetologia 2012;55:2622-2630.

7. Shah RV, Murthy VL, Abbasi SA, Blankstein R, Kwong RY, Goldfine AB, et al. Visceral adiposity and the risk of metabolic syndrome across body mass index: The mesa study. JACC Cardiovasc Imaging 2014;7:1221-1235.

8. Lee SY, Gallagher D. Assessment methods in human body composition. Curr Opin Clin Nutr Metab Care 2008; 11(5): 566-572.

9. Fosbøl MØ, Zerahn B. Contemporary methods of body composition measurement. Clin Physiol Funct Imaging 2015; 35 (2):81-97.

10. Lemos T, Gallagher D. Current body composition measurement techniques. Curr Opin Endocrinol Diabetes Obes 2017; 24 (5):310-314.

11. Ashwell M, Gibson S. Waist-to-height ratio as an indicator of 'early health risk': simpler and more predictive than using a 'matrix' based on BMI and waist circumference. BMJ Open 2016; 6(3):e010159. 
12. Faria SL, Faria OP, Cardeal MDA, Ito MK. Validation study of multi-frequency bioelectrical impedance with dual energy $x$-ray absoptiometry among obese patients. Obes Surg 2014; 24(9):1476-80.

13. Li YC, Li CI, Lin WY, Liu CS, Hsu HS, Lee CC, et al. Percentage of body fat assessment using bioelectrical impedance analysis and dual-energy X-ray absorptiometry in a weight loss program for obese or overweight Chinese adults. PLoS One 2013; 8(4): e58272.

14. Neeland IJ, Grundy SM, Li X, Adams-Huet B, Vega GL. Comparison of visceral fat mass measurement by dual-X-ray absorptiometry and magnetic resonance imaging in a multiethnic cohort: the Dallas Heart Study. Nutr Diabetes 2016; 6(7):e221.

15. Buckinx F, Reginster JY, Dardenne N, Croisiser JL, Kaux JF, Beaudart C, et al. Concordance between muscle mass assessed by bioelectrical impedance analysis and by dual energy X-ray absorptiometry: A cross-sectional study. BMC Musculoskelet Disord 2015; 16:60.

16. Ramírez-Vélez R, Tordecilla-Sanders A, Correa-Bautista JE, González-Ruíz K, González-Jiménez E, Triana-Reina HR, et al. Validation of multi-frequency bioelectrical impedance analysis versus dual-energy X-ray absorptiometry to measure body fat percentage in overweight/obese Colombian adults. Am J Hum Biol 2018; 30(1): 1-6.

17. Vega GL, Adams-Huet B, Peshock R et al. Influence of body fat content and distribution on variation in metabolic risk. J Clin Endocrinol Metab 2006; 91:4459-4466.

18. Patel S, Unwin N, Bhopal R, White M, Harland J, Ayis SA, et al. A comparison of proxy measures of abdominal obesity in Chinese, European and South Asian adults. Diabet Med 1999; 16(10):853-60.

19. Després JP, Lemieux I. Abdominal obesity and metabolic syndrome. Nature 2006; 444:881-887.

20. Bertin E, Marcus C, Ruiz JC, Eschard JP, Leutenegger M. Measurement of visceral adipose tissue by DXA combined with anthropometry in obese humans. Int J Obesity 2000; 24: 263-270.

21. Miazgowski T, Kucharski R, Sołtysiak M, Taszarek A, Miazgowski B, Widecka $\mathrm{K}$. Visceral fat reference values derived from healthy European men and women aged 20-30 years using GE Healthcare dual-energy x-ray absorptiometry. PLoS One 2017;12(7): e0180614.

22. Rockamann RA, Dalton EK, Arabas JL, Jorn L, Mayhew JL. Validity of arm-toarm bia devices compared to dxa for estimating $\%$ fat in college men and women. Int J Exerc Sci 2017; 10(7):977-988. eCollection 2017.

23. Lee DH, Park KS, Ahn S, Ku EJ, Jung KY, Kim YJ, et al. Comparison of Abdominal Visceral Adipose Tissue Area Measured by Computed Tomography with That Estimated by Bioelectrical Impedance Analysis Method in Korean Subjects. Nutrients 2015; 7(12): 10513-24.

24. Wang ZH, Yang ZP, Wang XJ, Dong YH, Ma J. Comparative Analysis of the multi-frequency bio-impedance and dual-energy x-ray absorptiometry on body composition in obese subjects. Biomed Environ Sci 2018; 31(1):72-75.

25. Chen KT, Chen YY, Wang CW, Chuang CL, Chiang LM, Lai CL, et al. Comparison of standing posture bioelectrical impedance analysis with dxa for body composition in a large, healthy chinese population. PLoS One 2016; 11(7): e0160105.

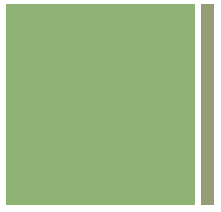

Corresponding author

Lara Benigno Porto

Unit of Endocrinology. Regional Hospital ofTaguatinga.

Área Especial No 24, Setor C Norte,

Taguatinga, Brasília - DF, CEP 72115-902

Email: larabporto@yahoo.com.br 